vehicles. In many ways the interests of coal and its derivative electricity appear to be much the same. The dernand by electric power stations on the collierics for 'slacks', 'duff' and rough 'smalls' now exeeeds the supply, although coal-breaking and crushing plant has been installed at a number of collieries. This would naturally add to the cost of production.

\section{Water-cooled Lamps for Television}

A serious difficulty in television studios is the necessity of providing about double the light required by an ordinary cinema studio without subjecting the occupants and contents to intolerable heat. This difficulty has been largely overcome by the General Electric Co. of America at the television station at Schenectady, New York, by the use of a battery of four water-cooled quartz mercury arc units, containing twelve argon-filled lamps having a light output equivalent to that provided by nearly 30,000 watts of incandescent light, but they give off practically no appreciable arnount of heat. According to the Electrical Review of August 25, the lamps aro about the size of a cigaretto and have an exterior of quartz. Surrounding the tube is another quartz jacket through which water passes at the rate of threo quarts a minute, dispersing about 90 per cent of the heat generated. The twelve 1,000-watt lamps used have a total light output of about 800 thousand lumens, while the same wattage of incandescent lamps would provide only 330 thousand lumens. The possibility of a burn from incandescent lamps, caused by the infra. red radiation, greatly inconveniences performers who appear before the television camcra. In the case of the new lamps, more than 90 per cent of the infra-red radiation is absorbed by tho circulating water. The cooling system of the lamps is equipped with § pressure-operated switch and magnetic valve, since the water in the jacket must be moving before the lamp is lighted and because the lamp must bo turned off automatically in the ovent of failuro or reduction of the water supply. During operation a pressure of more than $1,000 \mathrm{lb}$. per sq. in. is developed within the quartz jacket.

\section{Railway Electrification at Home and Abroad}

Aricuougin the date of opening of the electrified route between Manchester and Sheffield las not yet been fixed, orders have been placed for soventy electric locomotives. This follows on the orders for eight multiple-unit trains between Manchester and Glossop. During the last two months a number of now electric services in Kent havo been opened. According to the Beama Journal of August, the Southern Railway now possesses 3,189 electrically operated passenger vehicles, of which 603 cars have equipment designed for a maximum speed of 75 miles per hour and the remainder of 60 m.p.h. These speeds appear slow when compared with the rated speeds of Continental expresses. It must be remem. bered that the Southern Railway undertaking is a huge suburban network, in which high average speed is of the greatest importance. The problem of the London-Brighton railway is very different from that of the line joining Milan and Brescia. For the latter route an electric locomotivo with a commercial speed of $91 \mathrm{~m} . \mathrm{p} . \mathrm{h}$. has just been designed. In preparation for the forthcoming electrified link between Berlin and Munich, tho German State Railways have accepted a locomotivo with an ordinary speed of 112 m.p.h. and a possible maximum of 1.40 m.p.h. The use of locomotives of this type will, it is believed, reduco the journey time between Berlin and Munich from eight to fivo and a half hours.

\section{Health of the Army in India during 1937}

Statistics of the health of the British and Indian troops in India aro contained in tho recently issued "Annual Report of the Public Health Commissioner with the Government of India for 1937", 2 (Government of India Press, New Delhi. Rs. 2-6, or 4s.). 'Tho year 1937 was, from the health aspect, a good year for both British and Indian troops. There was a reduction in hospital admissions among both groups as compared with 1936 (also a good year) of 14.3 per 1,000 of strength among British troops, and 37.0 among Indian troops. Although the admission ratio appears to bo on the downward trend, conditions cannot bo considered satisfactory accord. ing to modern health standards so long as 568 out of overy 1,000 British soldiers and 390 out of every 1,000 Indian soldiers are admitted to hospital during the course of a year. Compared with the troops in the United Kingdom, tho hospital admission ratio in India is almost exactly double. The reasons aro partly climatic, and partly due to the moro primitive methods of sanitation, both in the army and among the civil populations in contact with it. Thero has been, however, a reduction in incidenco of such diseases as malaria and tho enteric groups of fovers. A now synthetic drug named 'Certuna' has given promising results in the treatment of sub-tertian malaria. Information is given of the work being done to supply pure water to the stations, on conservancy systems, and on the sanitary control of milk and foods.

\section{Work of Indian Medical Institutes}

THE reports of the Haffline Institute for 1938 and of the Pasteur Institute of India, Kasauli, for 1937, have reached us. The Haffkine Institute is the centre for the preparation of Haffkine's preventive plague vaccine, of which $1,137,086$ doses wero issued during the year. Some trials of the Institute's antiplague serum were made in a small outbreak of plague, with a mortality of about 26 per cent, compared with a mortality of about 63 per cent with other non-specific treatments. Two of tho sulphanilamide drugs, Prontosil and M. and B. 693, so valuable in streptococcal infections, wero tried in plague but showed little or no curativo power. A number of research studies on plague vaccino and serum, anti-malaria drugs, human and rat leprosy, fleas, and other subjects aro summarized. At the Fasauli Pasteur Institute, anti-rabic treatment is carried out. The total number of patients attending tho Institute and its centres was 28,076 , of whom 